\title{
Composing biodiversity indicators for the conservation of mangrove ecosystem in Xuan Thuy National Park, Vietnam
}

\author{
Xây dưng chỉ thị đa dạng sinh hoc cho bảo tồn hệ sinh thái rù̀ng ngập mặn ở \\ Vuoòn quốc gia Xuân Thủy, Việt Nam \\ Research article
}

Haneji, Choshin ${ }^{1}$; Do, Van Tu²; Vu, Duc Loi ${ }^{3}$; Duong, Tuan Hung ${ }^{3}$

${ }^{I}$ Graduate School of Environment and Information Sciences, Yokohama National University, Japan; ${ }^{2}$ Institute of Ecology and Biological Resources, Vietnam Academy of Science and Technology; ${ }^{3}$ Institute of Chemistry, Vietnam Academy of Science and Technology

\begin{abstract}
Biodiversity indicators for the conservation of mangrove ecosystems of Xuan Thuy National Park were composed, taking into account the environmental, biotic, and anthropological factors, based on suggested indicators provided by the Convention on Biological Diversity. Relevant environmental, biotic, and anthropological factors, identified by bibliographic and field surveys, were ordered by Pressures, State, Benefits, and Responses categories following the guidance of the Biodiversity Indicators Partnership. Furthermore, the linked relationships among the indicators were identified for effective monitoring of biodiversity in Xuan Thuy National Park.

Dựa trên các chỉ thị được gợi ý tù Công uoóc về Đa dạng sinh học, các chỉ thị đa dạng sinh học phục vu công tác bảo tồn các hệ sinh thái rùng ngập mặn của Vườn Quốc gia Xuân Thủy đã được xây dựng, có tính đến các yếu tố môi trương, sinh học và con người. Các yếu tố môi trường, sinh học và con người có liên quan, được xác định bằng việc tổng hợp và đánh giá các tài liệu và các đợt điều tra ngoài thục địa, duới trật tụ các nhóm Áp lực, Tình trang, Lợi ích và Đáp ứng theo hướng dẫn của Đối tác chỉ thị đa dạng sinh học. Hơn thế nũa, các mối quan hệ liên kết giữa các chỉ thị đã được xác định nhằm quan trắc hiệu quả đa dạng sinh học ở Vườn Quốc gia Xuân Thủy.
\end{abstract}

Keywords: $\quad$ biodiversity indicator, Xuan Thuy National Park, mangrove ecosystem

\section{Introduction}

In November 2011, The Convention on Biological Diversity (CBD) communicate to the Parties a suggested indicator framework for assessing progress in the implementation of the 2020 Biodiversity target constituted by a set of headline indicators, under which operational indicators classified by categories.

CBD states that the 2020 Biodiversity target and proposed indicator framework provide a flexible framework for Parties to be adapted taking into account national priorities and circumstances. And, for most indicators it is likely that countries will use different metrics and methodologies for their indicators depending on national targets and available data and methods (UNEP/CBD/SBSTTA, 2011).
The objective of the present work consisting in proposing a set of relevant monitoring variables for composing biodiversity indicators related with the conservation of mangrove ecosystems of Xuan Thuy National Park (XTNP) based on the suggested indicator framework by CBD and taking into account the main concern and capacities of Vietnamese institutions.

\section{Materials and methods}

In order to recognize the features of the mangrove ecosystem of XTNP a series of surveys, combining bibliographic search works and field activities, were conducted. 


\subsection{Soil and water properties measurement}

The characterization of environmental features of mangrove ecosystem is a huge challenging work, because of the high affection by the tide cycles. Especially, a single set of spot measurements of water properties is almost helpless for understanding the real scenario. As cited in Mazda (2011), properties such as water temperature, salinity, and dissolved oxygen, can fluctuate enormously with the tide cycle. Those parameters measured in the same point with some hours of difference can change several folds in value.

However, in order to have an idea of the features of the ecosystem in XTNP, surveys of soil and water properties were conducted with the purpose to characterize quantitatively their behaviours and to correlate with the existing biota.

\subsection{Analysis of collected data}

The collected data of soil and water properties were analysed, using interpolation based on inverse distance weighting (IDW), in order to gather a distribution path rasters of those data using a plugin function of QGIS 2.2.0-Valmiera.

\subsection{Selection of biodiversity indicators for XTNP}

Having the ready to use globally indicators of the set of suggested indicator framework from CBD, it was analysed first the site-relevancy of its headline and operational indicators for XTNP.

The categorization of indicators and concept on linked relationship among the indicators was referred to "Biodiversity indicators and the 2010 Target: Experiences and lessons learnt from the 2010 Biodiversity Indicators Partnership" (2010 Biodiversity Indicators Partnership, 2010).

The concepts on monitoring activities were referred basically to "Guidance for national biodiversity indicators development and use" (Biodiversity Indicators Partnership, 2011).

\section{Results and Discussion}

\subsection{Total organic carbon in surficial soil}

The higher values of TOC were shown where is spreading the natural mangrove forest. Following to this pattern, lesser values were observed in planted mangrove areas (Haneji et al., 2014a).

TOC values in plots where mangroves is standing ranged 2.0-2.9\%, while for the plot dominated by Casuarina equisetifolia and without mangrove species was ten-folds lower $(0.2 \%)$.
According to Tue et al., (2012), the biogeochemical research work in XTNP showed that contributions of mangrove and marine phytoplankton sources to sedimentary organic carbon, resulted that mangrove material decreased as follows: natural mangrove forest $>$ planted mangrove $>$ tidal flat $>$ creek bank $>$ creek bottom $>$ sub-tidal habitat.

The behaviour that we found in XTNP with respect of TOC concentrations corroborate the statement of Tue et al. (2012) with a tendency of high TOC concentrations in natural growth mangrove area, and sequenced by planted mangrove area, and non-mangrove area. In that sense, it can be inferred that TOC contribution to the soil by natural mangrove is the highest in the area.

\subsection{Coliforms in streams and surficial soil pore waters}

The measured values of coliforms in XTNP differed considerably between winter and summer seasons. The surficial soils pore water measurements ranged for winter season 103-4,920 MPN/100 mL; while for summer season 402-46,110 MPN/100 mL Eight of 15 measurements resulted impaired with Vietnamese regulation in winter season; and 12 impaired results were observed out of 16 in summer season (The National Technical Regulation on Coastal Water Quality: QCVN 10: 2008/BTNMT establishes for coliforms, a maximum level of 1,000 MPN/100mL as quality standard, for aquaculture and aquatic conservation waters).

It is notorious that higher values are closer to drainage systems of shrimp ponds. By the other hand, the measured values for surficial waters showed lesser higher values compared with those of pore waters. Winter season values ranged 42-3,065 MPN/100 $\mathrm{mL}$ and summer season 80$12,098 \mathrm{MPN} / 100 \mathrm{~mL}$. Due that values inside the shrimp ponds are higher than outside, it can be inferred that coliforms are originated from the aquaculture activity. In that sense, the aforementioned statement of Anh et al. (2010), water pollution is largely associated with the use and discharge of water in shrimp ponds can be observed also for XTNP.

\subsection{Toxic metals in streams and surficial soil pore waters}

The National Recommended Water Quality Criteria of the United States Environmental Protection Agency (EPA) establishes Criterion Continuous Concentration (CCC) for priority toxic pollutants as an estimate of the highest concentration of a material in surface water to which an aquatic community can be exposed indefinitely without resulting in an unacceptable effect (EPA, 2006). The National Technical Regulation on Coastal Water Quality (QCVN 10: 2008/BTNMT) of Vietnam establishes for a group of metalloids and metals quality standards for aquaculture and aquatic conservation waters. The correspondent values are listed in Table 1.

Taking into account the threshold values listed in Table 1, respective values for arsenic, cadmium, mercury, and 
nickel resulted paired. With respect of other toxic metals, the results of measurements are described in below.

Table 1. Criterion Continuous Concentrations and Vietnamese standards for metals

\begin{tabular}{lrrr}
\hline Element & CCC for freshwater & CCC for saltwater & Standard for aquaculture and aquatic conservation \\
\hline Arsenic & $150 \mu \mathrm{g} / \mathrm{L}$ & $36 \mu \mathrm{g} / \mathrm{L}$ & $0.01 \mathrm{mg} / \mathrm{L}(10 \mu \mathrm{g} / \mathrm{L})$ \\
Cadmium & $0.25 \mu \mathrm{g} / \mathrm{L}$ & $8.8 \mu \mathrm{g} / \mathrm{L}$ & $0.005 \mathrm{mg} / \mathrm{L}(50 \mu \mathrm{g} / \mathrm{L})$ \\
Copper & $9.0 \mu \mathrm{g} / \mathrm{L}$ & $3.1 \mu \mathrm{g} / \mathrm{L}$ & $0.03 \mathrm{mg} / \mathrm{L}(30 \mu \mathrm{g} / \mathrm{L})$ \\
Lead & $2.5 \mu \mathrm{g} / \mathrm{L}$ & $8.1 \mu \mathrm{g} / \mathrm{L}$ & $0.05 \mathrm{mg} / \mathrm{L}(50 \mu \mathrm{g} / \mathrm{L})$ \\
Mercury & $0.77 \mu \mathrm{g} / \mathrm{L}$ & $0.94 \mu \mathrm{g} / \mathrm{L}$ & $0.001 \mathrm{mg} / \mathrm{L}(1 \mu \mathrm{g} / \mathrm{L})$ \\
Nickel & $52 \mu \mathrm{g} / \mathrm{L}$ & $8.2 \mu \mathrm{g} / \mathrm{L}$ & Not regulated \\
Zinc & $120 \mu \mathrm{g} / \mathrm{L}$ & $81 \mu \mathrm{g} / \mathrm{L}$ & $0.05 \mathrm{mg} / \mathrm{L}(50 \mu \mathrm{g} / \mathrm{L})$ \\
\hline
\end{tabular}

The measured values of copper concentration in surficial waters ranged between 1.7-3.9 $\mu \mathrm{g} / \mathrm{L}$ during December 2012. In result, out of 20 measurements, eight were impaired with respective CCC for saltwater environment.
Figure 1 shows the tendency of higher concentration of copper surrounding the drainage system of shrimp ponds. Herbicides based on sulphate copper are used for cleaning shrimp ponds, because of that it can be inferred that those cleaning activities is generating the anomalous values of copper in XTNP.

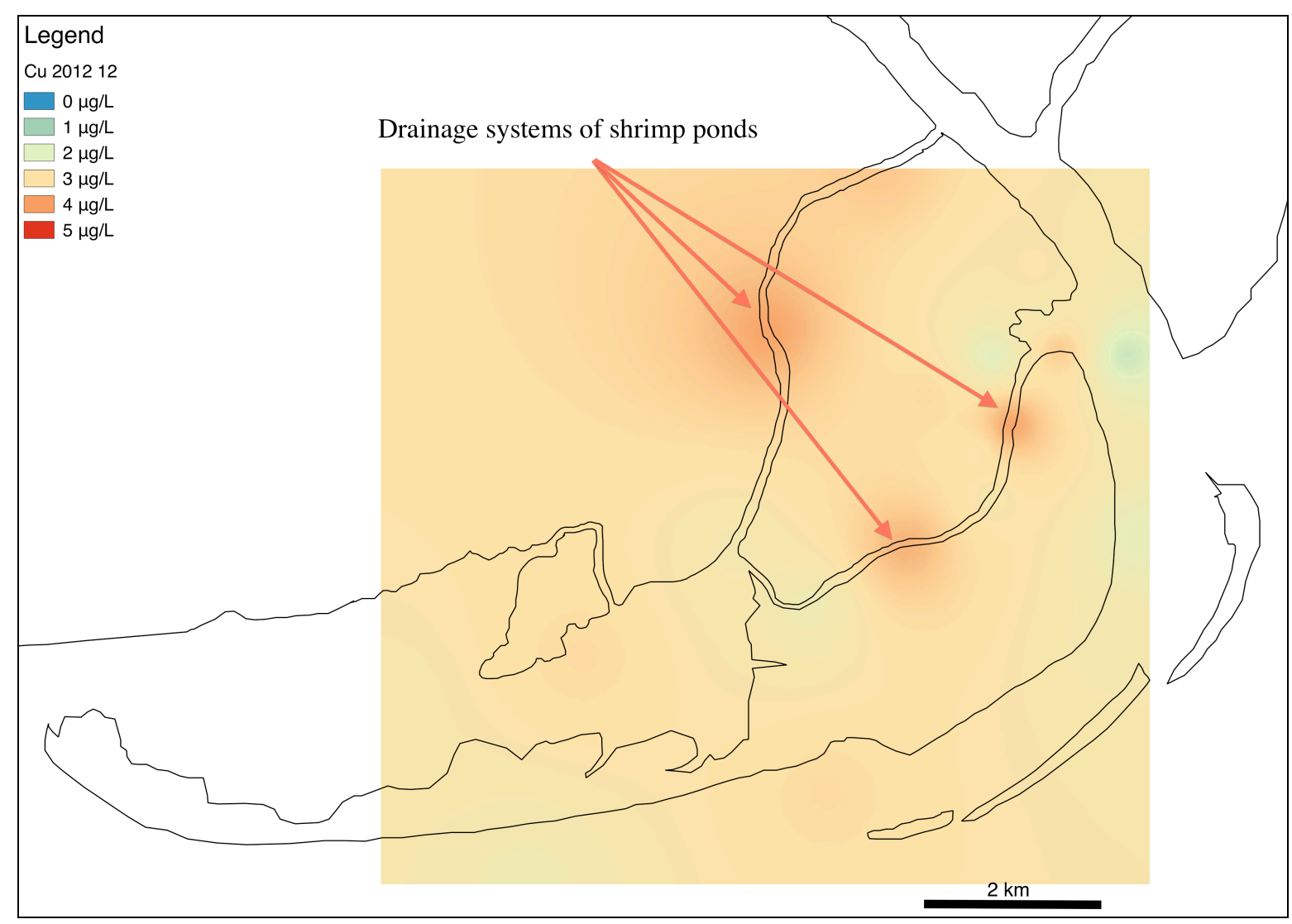

Figure 1. Distribution path of copper concentration in surficial water in winter season (IDW-interpolated)

All measured concentrations of lead result lower than CCC for saltwater. However, because of river dominant behaviour of XTNP, it is recommendable to monitor the water quality also with CCC for freshwater environments. Out of total 74 (31 for surficial soil pore water and 43 for surficial water) measurements impaired against freshwater CCC were observed in 30 measurements (18 of pore water and 12 of surficial water). The Figure 2 shows the distribution path of lead concentration in surficial waters measured in December 2012.
As shown in Figure 2 anomalous concentrations of lead are ubiquitous. These locations coincide with shipping docks and transportation routes of sand extraction activities for clam culture.

With respect of zinc concentrations, measured values were under the CCC thresholds. However, under the stringent Vietnamese regulation two points showed impaired situations. 


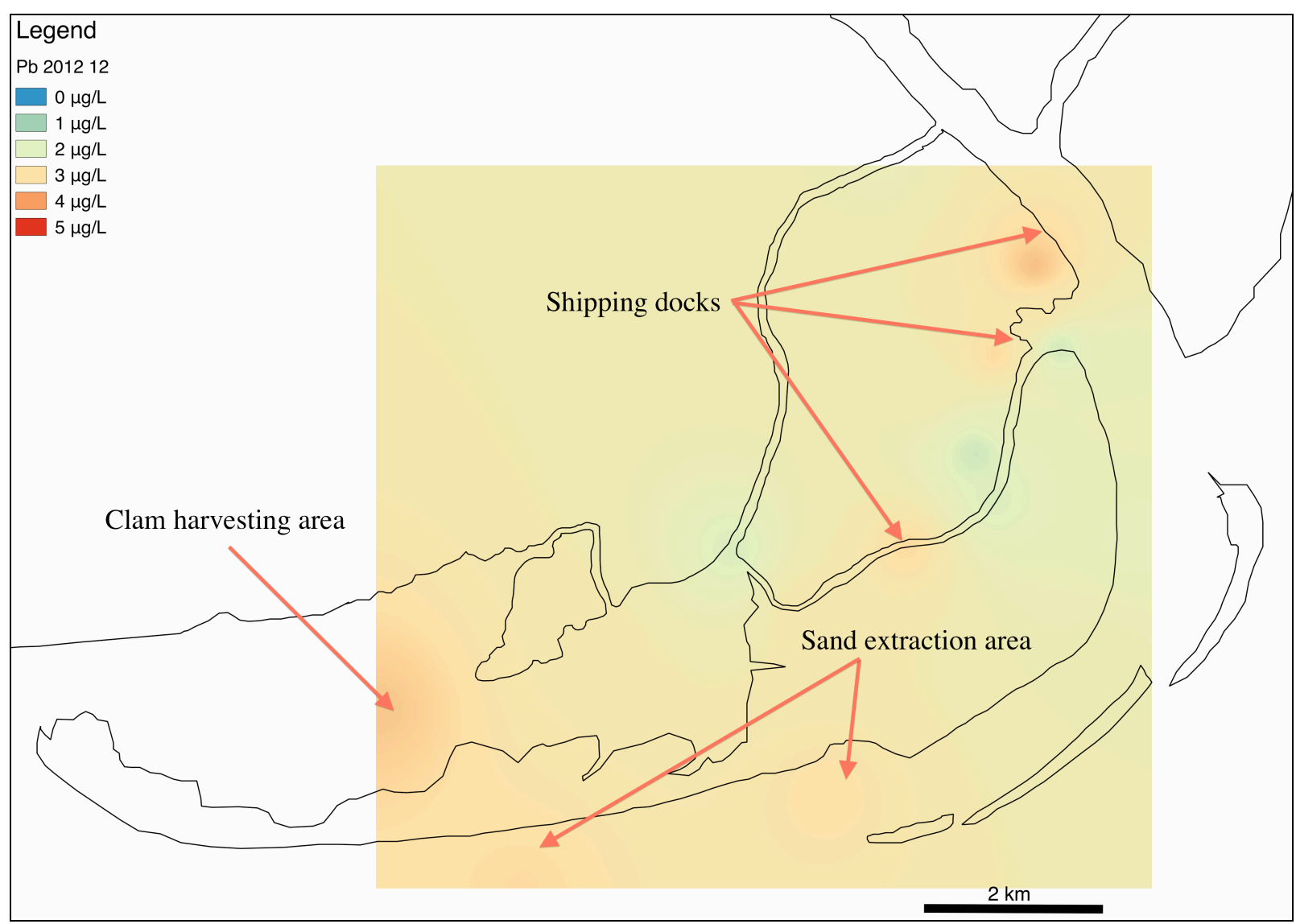

Figure 2. Distribution path of lead concentration in surficial water in winter season (IDW-interpolated)

The foremost higher concentration of zinc was observed in the zone of clam culture. It is known that clams have capacity to accumulate zinc. The American Society for Testing and Materials (2001) defines bioaccumulation as the net accumulation of a chemical into the tissues of an organism as a result of uptake from all environmental sources, both food and ambient water. According to Luoma and Rainbow (2008), the bioaccumulation is influenced by the chemistry of the specific metal, how that metal reacts with the environment and species-specific physiological and ecological traits. And also, the uptake of trace metals from solutions by an aquatic organism is primarily concentration dependent.

The higher the dissolved concentration of the trace metal, the higher will be the uptake rate of the metal from solution into the organism. Furthermore, the uptake rates follows a consistent metal-specific rank order among most of species as follows: silver $>$ zinc $>$ cadmium $>$ copper $>$ cobalt $>$ chromium $>$ selenium.

The reason of high zinc concentrations can be related to this selective bioaccumulation and its consequent burial in the surrounding environment, however it is recommended to recognize the sources of zinc in order to understand the accumulation mechanism of the trace metal in the area.

\subsection{Composing biodiversity indicators}

\subsubsection{Pressures category indicators}

\section{Population trends of habitat dependent species in each major habitat type}

Based on Haneji et al. (2014a) Aegiceras corniculatum is the foremost contributor to aboveground biomass (AGB) in the area, and Sonneratia caseolaris dominates at southern zone and co-exists with $A$. corniculatum at northern zone of XTNP. The measurement of population of these native and naturally growing species are suitable to consider as monitoring variables for mangrove species.

It was recognized that macroinvertebrate species are more abundant and diverse in tidal-flats with mangroves than those without mangroves. In addition, was also recognized the associative relation of most of the macroinvertebrate species with specific mangrove species (Haneji et al., 2014b). Taking into account these results and the analysis of indicator species, the measurement of population of Paracleistostoma crabs in an annual basis, the polychaeta species of Nephtyidae for summer and Sesar$m a$ crabs for winter season are suitable to consider as monitoring variables for macroinvertebrate species.

\section{Trends in water quality in aquatic ecosystems}

High concentrations of copper and coliform accounts in water is inferred that is originated by shrimp ponds, high concentration of lead in water by the shoreline transportation and sand extraction activities, and high concentration of zinc associated with clam harvesting activities. 
The inferred bioaccumulation and sink of zinc in clam harvesting areas should also be considered.

By the other hand, according to Le and Munekage (2004) and Le et al. (2003) remnant antibiotics used in shrimp ponds of XTNP are draining with their effluents to the surrounding environment. Our field surveys had no enough resources for analysing the existence of this problem in field. However, it is recommended to consider as monitoring variable.

\subsubsection{State category indicators}

\section{Trends in extent of selected ecosystems and habitats}

According to Seto and Fragkias (2007), in 1975, the area of XTNP was completely absent of aquaculture ponds for shrimp culture. However, by 2002, the entire region of Ngan islet was extensively used for shrimp culture. Consistent with this affirmation, Lebel et al. (2002a, 2002b) informed that shrimp farming in Vietnam began intensively at the end of the 1990's in response to international market demand and supported by government policies on coastal land conversion.

Furthermore, based on Anh et al. (2010) shrimp culture systems have gradually shifted from traditional systems based on the use of natural tide cycle and mangrove plants inside the ponds for shelter and food for shrimp into extensive production with pumping system for water exchange, artificial feeding, and increased stocking densities. Although traditional and improved farming systems continue to exist in parallel, production does appear to have intensified. During the past ten years shrimp production increased faster than the area of shrimp ponds.

The ecosystems of importance in XTNP consisted on mangals, sandyflats, and casuarina woodlands. In addition, aquaculture ponds and the coastal area of clam harvesting should consider because they are habitats for several species.

\subsubsection{Benefits category indicators}

Trends in benefits that humans derive from selected ecosystem services

It is obvious that the biggest ecosystem services derived from the resources of XTNP are the production yields of aquaculture activities in Giao Thuy district. Shrimp and clams are the representative products. Following to the aquaculture activities fishing and bycatch activities are also important.

In addition, the compilation of bibliographic survey and observations in field survey concerning the ecosystem services gathering by the local people from abundant mangrove species are listed in Table 2.

Status and trends in extent and condition of habitats that provide carbon storage

As was discussed, it is inferred that the principal contributor of carbon storage of XTNP are the natural mangrove forest, followed by planted mangroves. This is corroborated by the statement that in general, the total net primary production of mangrove ecosystems has been estimated at $218 \pm 72 \mathrm{Tg} \mathrm{C} /$ year (Bouillon et al., 2003; Twilley et al., 1992), ranking as one of the most productive biomes on earth.

The combination of above proposed variables for "Population trends of habitat dependent species in each major habitat type": population counts of $A$. corniculatum and $S$. caseolaris in pre-established plots taking measurements of tree height and diameter at breast height $(\mathrm{DBH})$, and "Trends in extent of selected biomes, ecosystems and habitats": Mangrove area in core zone and Mangrove area in buffer zone can serve as referential information.

Hence, the recommended monitoring variable for this operational indicator is the value of carbon storage correlated with estimated aboveground biomass (AGB) in core zone calculated by the product of Mangrove area in core zone by estimated value of AGB of $A$. corniculatum and $S$. caseolaris per monitoring plot.

\subsubsection{Responses category indicators}

Trends in protected area condition and/or management effectiveness including more equitable management

Because of fishing activity is one the most important benefit sharing of resources in XTNP, it is necessary to establish a mechanism of information sharing of the fishing cooperatives with the respective communes of Giao Thuy district, the jurisdiction of XTNP.

The loss of mangrove relied on land reclamation of mangrove zones into shrimp pond construction. In order to conserve mangrove zones of XTNP, it is necessary to rise awareness on management of land use by the communes of Giao Thuy district.

Furthermore, water quality degradation was found in XTNP. Coliforms, and copper contamination are inferred have relation with shrimp culture activity. Lead contamination with ship transportation and sand extraction activities; and zinc accumulation inherent to calm harvesting activities. Compliance on sustainable development is necessary to be enforced in order to mitigate those disturbances.

Table 2. Ecosystem services from abundant mangrove species

\begin{tabular}{llll}
\hline Species & IUCN (2014) & $\begin{array}{l}\text { Hong and San } \\
(1993)\end{array}$ & Giesen et al. (2006) \\
\hline $\begin{array}{l}\text { Aegiceras } \\
\text { corniculatum }\end{array}$ & $\begin{array}{l}\text { The bark is used as a fish poison } \\
\text { and as a dye. It is also used as a }\end{array}$ & $\begin{array}{l}\text { Bark as fire- } \\
\text { wood. Roots for }\end{array}$ & $\begin{array}{l}\text { The saponin-containing bark is used to } \\
\text { stupefy fish. Flowers are used as orna- }\end{array}$ \\
\hline
\end{tabular}




\begin{tabular}{|c|c|c|c|c|}
\hline Species & IUCN (2014) & $\begin{array}{l}\text { Hong and San } \\
\text { (1993) }\end{array}$ & Giesen et al. (2006) & $\begin{array}{l}\text { Field observa- } \\
\text { tion }\end{array}$ \\
\hline & $\begin{array}{l}\text { medicine. The leaves are also } \\
\text { eaten. }\end{array}$ & $\begin{array}{l}\text { fishing poison. } \\
\text { Bee honey and } \\
\text { wax production. }\end{array}$ & $\begin{array}{l}\text { mental because of their fragrance. Wood } \\
\text { used for charcoal production. Young } \\
\text { leaves are edible. The flowers of this } \\
\text { species are an important source of nectar, } \\
\text { and may be important for local honey } \\
\text { industries. }\end{array}$ & $\begin{array}{l}\text { honey and wax } \\
\text { production. }\end{array}$ \\
\hline $\begin{array}{l}\text { Sonneratia } \\
\text { caseolaris }\end{array}$ & $\begin{array}{l}\text { Fruits are used as a beverage } \\
\text { and pickled. Pneumatophores } \\
\text { are used as cork and floats. } \\
\text { Timber is used for various } \\
\text { constructions and as fuelwood. } \\
\text { Leaves are used as forage, and } \\
\text { tannins from bark for dyes. }\end{array}$ & $\begin{array}{l}\text { Bark as fire- } \\
\text { wood. }\end{array}$ & $\begin{array}{l}\text { The sour young fleshy fruit is edible. } \\
\text { Poor quality timber, but occasionally } \\
\text { used to salt-water piling. When better } \\
\text { firewood is not available, this wood is } \\
\text { used. After having been in water, the } \\
\text { pneumatophores are an inferior substitute } \\
\text { for cork. Pneumatophores are also used } \\
\text { for making wooden soles of shoes. }\end{array}$ & $\begin{array}{l}\text { Bark as fire- } \\
\text { wood. }\end{array}$ \\
\hline $\begin{array}{l}\text { Kandelia } \\
\text { candel }\end{array}$ & None. & $\begin{array}{l}\text { Bark as fire- } \\
\text { wood. Leaves as } \\
\text { fodder for cattle. } \\
\text { Bee honey and } \\
\text { wax production. }\end{array}$ & Mainly for firewood. & $\begin{array}{l}\text { Bark as fire- } \\
\text { wood. Bee } \\
\text { honey and wax } \\
\text { production. }\end{array}$ \\
\hline $\begin{array}{l}\text { Rhizophora } \\
\text { stylosa }\end{array}$ & $\begin{array}{l}\text { This species is used for fuel- } \\
\text { wood. }\end{array}$ & $\begin{array}{l}\text { Tannin extrac- } \\
\text { tion from bark. } \\
\text { Leaves as fodder } \\
\text { for cattle. }\end{array}$ & $\begin{array}{l}\text { As timber, firewood and for the produc- } \\
\text { tion of charcoal. Light wine and a con- } \\
\text { coction to cure haematuria (blood in } \\
\text { urine) are made from the fruit. }\end{array}$ & Used as timber \\
\hline $\begin{array}{l}\text { Acanthus } \\
\text { ilicifolius }\end{array}$ & $\begin{array}{l}\text { Can be used as medicine for } \\
\text { neuralgia and rheumatism. The } \\
\text { root (boiled in mustard oil) is } \\
\text { used in paralysis of limbs; water } \\
\text { extracted from the bark is used } \\
\text { to treat colds and skin allergies. }\end{array}$ & $\begin{array}{l}\text { Leaves used for } \\
\text { treating rheuma- } \\
\text { tism and ucural- } \\
\text { gia. }\end{array}$ & $\begin{array}{l}\text { Fruits is pounded and used as a blood } \\
\text { purifier and dressing for burns. Leaves } \\
\text { relieve rheumatism. A compress of the } \\
\text { fruit or roots is sometimes applied in } \\
\text { cases of snakebite and arrow poisoning. } \\
\text { Seeds are used to treat internal worms. } \\
\text { The plant is also used for fodder. }\end{array}$ & Medicinal use. \\
\hline
\end{tabular}

\subsection{Linked relationship of Indicators}

For the effective management of the recommended monitoring variables the linked relationships among the four categories should be cleared.
Taking into account the results and discussion of 3.4 "Composing biodiversity indicators", proposed and recommended monitoring variables can be ordered in a way of linked relationships as listed in Table 3. The Table 3 lists the monitoring variables beneath of respective operational indicators with pressures-state-benefits-responses linked relationships.

Table 3. Linked relationship among selected biodiversity indictors monitoring variables

\begin{tabular}{|c|c|c|c|}
\hline A. Pressures & B.State & C. Benefits & D. Responses \\
\hline $\begin{array}{l}\text { Population trends of habitat } \\
\text { dependent species in each } \\
\text { major habitat type: } \\
\text { - } \quad \text { Reduction on population } \\
\text { of A. corniculatum and } S \text {. } \\
\text { caseolaris. } \\
\text { - Reduction on population } \\
\text { of Paracleistostoma crabs } \\
\text { in an annual basis. } \\
\text { - Reduction on population } \\
\text { of polychaeta species of } \\
\text { Nephtyidae for summer. } \\
\text { Reduction on population } \\
\text { of gastropod Assiminea } \\
\text { species for winter. }\end{array}$ & $\begin{array}{l}\text { Trends in extent of selected } \\
\text { ecosystems and habitats: } \\
-\quad \begin{array}{l}\text { Mangrove forest area in } \\
\text { core zone }\end{array} \\
\text { - } \quad \begin{array}{l}\text { Mangrove forest area in } \\
\text { buffer zone. }\end{array} \\
\text { Trends in abundance of select- } \\
\text { ed species: } \\
\text { - Estimated value of AGB } \\
\text { of A. corniculatum and } S \text {. } \\
\text { caseolaris. } \\
\text { Populations per species of } \\
\text { Paracleistostoma crabs at } \\
\text { annual basis. } \\
\text { Populations per species of } \\
\text { the polychaeta species of } \\
\text { Nephtyidae for summer } \\
\text { season. }\end{array}$ & $\begin{array}{l}\text { Trends in benefits that humans } \\
\text { derive from selected ecosystem } \\
\text { services: } \\
\text { - } \quad \text { Production yield of cul- } \\
\text { tured shrimp, crab, and } \\
\text { fish per commune of } \\
\text { Giao Thuy district. } \\
\text { - Production yield of bee } \\
\text { honey and wax per com- } \\
\text { mune of Giao Thuy dis- } \\
\text { trict. } \\
\text { Status of logging of } \\
\text { mangrove species for } \\
\text { firewood use. } \\
\text { Status of usage of man- } \\
\text { grove species for medici- } \\
\text { nal use. }\end{array}$ & $\begin{array}{l}\text { Trends in protected area } \\
\text { condition and/or management } \\
\text { effectiveness including more } \\
\text { equitable management: } \\
\text { - Status of land use man- } \\
\text { agement at commune lev- } \\
\text { el in Giao Thuy district. } \\
\text { - Enforcement over aqua- } \\
\text { culture activity in core } \\
\text { zone. } \\
\text { Enforcement on practic- } \\
\text { ing sustainable produc- } \\
\text { tion. }\end{array}$ \\
\hline
\end{tabular}




\begin{tabular}{|c|c|c|c|}
\hline A. Pressures & B. State & C. Benefits & D. Responses \\
\hline & $\begin{array}{l}\text { Populations per species of } \\
\text { the gastropod Assiminea } \\
\text { for winter season. }\end{array}$ & & \\
\hline $\begin{array}{l}\text { Trends in water quality in } \\
\text { aquatic ecosystems: } \\
\text { - } \quad \text { Water quality in creeks } \\
\text { considering as parameters } \\
\text { copper, lead, zinc, coli- } \\
\text { forms, and pesticides and } \\
\text { antibiotics used in shrimp } \\
\text { ponds. } \\
\text { Consumption of shrimp } \\
\text { food per commune of } \\
\text { Giao Thuy district. } \\
\text { Consumption of sulphate } \\
\text { copper per commune of } \\
\text { Giao Thuy district. } \\
\text { Consumption of pesti- } \\
\text { cides per commune of } \\
\text { Giao Thuy district. } \\
\text { Consumption of antibiot- } \\
\text { ics per commune of Giao } \\
\text { Thuy district }\end{array}$ & $\begin{array}{l}\text { Trends in extent of selected } \\
\text { biomes, ecosystems and habi- } \\
\text { tats: } \\
-\quad \text { Shrimp pond area in core } \\
\text { zone. } \\
\text { - Shrimp pond area in } \\
\text { buffer zone by communes } \\
\text { of Giao Thuy district } \\
\text { specifying area of artifi- } \\
\text { cial systems. } \\
\text { Clam harvesting area in } \\
\text { core zone. } \\
\text { Clam harvesting area in } \\
\text { buffer zone by communes } \\
\text { of Giao Thuy district. } \\
\text { Trends in abundance of select- } \\
\text { ed species: } \\
\text { Population per species } \\
\text { and preferred habitats of } \\
\text { fish species. }\end{array}$ & $\begin{array}{l}\text { Trends in benefits that humans } \\
\text { derive from selected ecosystem } \\
\text { services: } \\
\text { - } \quad \text { Production yield of cul- } \\
\text { tured shrimp, crab, and } \\
\text { fish per commune of } \\
\text { Giao Thuy district. } \\
\text { Fishing yield of selected } \\
\text { species expreseed as pe- } \\
\text { cuniary index per com- } \\
\text { mune of Giao Thuy dis- } \\
\text { trict. }\end{array}$ & $\begin{array}{l}\text { Trends in protected area } \\
\text { condition and/or management } \\
\text { effectiveness including more } \\
\text { equitable management: } \\
-\quad \text { Enforcement on practic- } \\
\text { ing sustainable produc- } \\
\text { tion. } \\
\text { - } \quad \text { Enforcement on the use } \\
\text { of toxic compounds. } \\
\text { - Enforcement on the } \\
\text { carrying capacity in } \\
\text { shrimp ponds. } \\
\text { Enforcement on the } \\
\text { addition of food for } \\
\text { shrimps. }\end{array}$ \\
\hline $\begin{array}{l}\text { Population trends of habitat } \\
\text { dependent species in each } \\
\text { major habitat type: } \\
\text { - } \quad \text { Reduction on population } \\
\text { of Aegiceras cornicula- } \\
\text { tum and Sonneratia case- } \\
\text { olaris. }\end{array}$ & $\begin{array}{l}\text { Trends in extent of selected } \\
\text { biomes, ecosystems and habi- } \\
\text { tats: } \\
-\quad \begin{array}{l}\text { Mangrove area in core } \\
\text { zone }\end{array} \\
\text { Trends in abundance of select- } \\
\text { ed species: } \\
\text { - Estimated value of AGB } \\
\text { of } A \text {. corniculatum and } S \text {. } \\
\text { caseolaris. }\end{array}$ & $\begin{array}{l}\text { Status and trends in extent and } \\
\text { condition of habitats that } \\
\text { provide carbon storage: } \\
\text { - Value of carbon storage } \\
\text { correlated with estimated } \\
\text { AGB in core zone. }\end{array}$ & $\begin{array}{l}\text { Trends in protected area } \\
\text { condition and/or management } \\
\text { effectiveness including more } \\
\text { equitable management: } \\
\text { - } \quad \text { Status of land use man- } \\
\text { agement at commune lev- } \\
\text { el in Giao Thuy district. } \\
\text { - Enforcement over aqua- } \\
\text { culture activity in core } \\
\text { zone. }\end{array}$ \\
\hline
\end{tabular}

\section{Conclusions}

\subsection{Soil and water properties}

It was recognized that values of organic carbon in soil is highest in areas with natural mangroves; and following to this the area of planted mangroves; and much lower for areas without mangroves. Extremely high values of coliforms index were found inside the shrimp ponds and in surrounding water of water channelling system for shrimp culture. Anomalous values of toxic metals such as lead and zinc requires additional approach in order to recognize their mechanism of contamination. However, it is suggested that ship transportation and sand extraction in shoreline areas have relation with lead contamination; and clam harvesting for zinc accumulation. Unpaired concentrations of copper were found surrounding the water channelling systems for shrimp culture. Because is known that the sulphate copper is used as herbicide for cleaning the shrimp ponds, the cause of contamination is evident.

\subsection{Biodiversity indicators}

Monitoring variables for a group of priority and ready to use globally indicators have been selected based on the characterization of mangrove ecosystem of XTNP, demonstrating the usefulness of categorization approach proposed by CBD for creating the linked relationship of selected indicators and monitoring variables. Understandings on the carrying capacity of aquaculture activity and sustainable production, especially on proper addition of food -rich in nutrients- for shrimp, are urgent issues.

By the time of writing this paper, the Ministry of Natural Resources and Environment was drafting a regulation bill concerning establishment of an administrative unit under provincial Department of Natural Resources and Environment (DoNRE) in charge of management of biodiversity in their jurisdictions. With the establishment of those units of biodiversity management in provincial DoNRE, it is expected that implementation of biodiversity monitoring using the methodologies proposed in this thesis will be facilitated. 


\section{References}

[1] Anh, P.T., Kroeze, C., Bush, S.R., Mol, A.P.J., 2010. Water pollution by intensive brackish shrimp farming in south-east Vietnam: Causes and options for control. Agricultural Water Management 97, 872-882.

[2] ASTM (American Society for Testing and Materials). 2001. Standard terminology relating to biological effects and environmental fate. E 943-000. In Annual Book of ASTM Standards, Vol. 11.05. pp. 246-248.

[3] Biodiversity Indicators Partnership. 2011. Guidance for national biodiversity indicator development and use. UNEP World Conservation Monitoring Centre, Cambridge, UK. 40pp.

[4] Bouillon, S., Dahdouh-Guebas, F., Rao, A. V. V. S., Koedam, N., and Dehairs, F. 2003. Sources of organic carbon in mangrove sediments: variability and possible ecological implications. Hydrobiologia 495: 33-39.

[5] EPA (United States Environmental Protection Agency). 2006. National Recommended Water Quality Criteria. Office of Water, Office of Science and Technology (4304T).

[6] Giesen, W., Wulffraat, S., Zieren, M. and Scholten, L. 2006. Mangrove Guidebook for Southeast Asia. FAO and Wetlands International.

[7] Haneji, C., Amemiya, T., Itoh, K., Mochida, Y., Nhan, H.T.T., and Cu, P.V. 2014a. Analysis of environmental stressors on ecosystems of XTNP, Vietnam. Journal of Vietnamese Environment. Vol. 5, No. 1, pp. 12-21.

[8] Haneji, C., Tu, D.V., Cuong, N.T., and Anh, T.T.P. 2014b. Behaviour of Macroinvertebrate Species in Xuan Thuy National Park, Vietnam (unpublished paper).

[9] Hong, P. N., and San, H. T. 1993. Mangroves of Vietnam. The IUCN Wetland Programme, IUCN, Bangkok, Thailand, $173 \mathrm{pp}$.

[10] IUCN. 2014. The IUCN Red List of Threatened Species, 2014.2. (Website: www.iucnredlist.org).

[11] Le, T.X., Munekage, Y., 2004. Residues of selected antibiotics in water and mud from shrimp ponds in mangrove areas in Viet Nam. Marine Pollution Bulletin 49, 922-929.

[12] Le, T. X., Munekage, Y., Phan, D.A.T., Quan, D.Q.Thi, 2003. The environmental quality of shrimp ponds in mangrove areas. Proceedings of the Thirteenth, International Offshore and Polar Engineering Conference Honolulu, HI, USA, May 25-30; ISSN: 1098-6189 (set) 1-880653-60-5 (set). p. 255-62.

[13] Lebel, L., Tri, N.H., Saengnoree, A., Pasong, S., Buatama, U., Thoa, L.K., 2002a. Industrial transformation and shrimp aquaculture in Thailand and Vietnam: pathways to ecological. Social, and economic sustainability\&\#63. AMBIO: A Journal of the Human Environment 31, 311-323.

[14] Lebel, L., Tri, N.H., Saengnoree, A., Pasong, S., Buatama, U., Thoa, L.K., 2002b. Industrial transformation and shrimp aquaculture in Thailand and Vietnam: pathways to ecological, social, and economic sustainability? AMBIO 31 (4), 311-323.

[15] Luoma, S. N. and Rainbow, P. S. Metal Contamination in Aquatic Environments: Science and Lateral Management. 2008. Cambridge University Press, Cambridge. ISBN 978-0-521-27901-7.

[16] Mazda, Y. 2011. Environmental physics of Mangroves. Tokai University Press, 2011. ISBN978-4486-01901-5.

[17] Seto, K., Fragkias, M., 2007. Mangrove conversion and aquaculture development in Vietnam: A remote sensing-based approach for evaluating the Ramsar Convention on Wetlands. Global Environmental Change 17: 486-500.

[18] Tue, N. T., Hamaoka, H., Sogabe, A., Quy, T. D., Nhuan, M. T., and Omori, K. 2012. Food sources of macro-invertebrates in an important mangrove ecosystem of Vietnam determined by dual stable isotope signatures. Journal of Sea Research 72: 14-21.

[19] Twilley, R. R., Chen, R. H., and Hargis, T. 1992. Carbon sinks in mangroves and their implications to carbon budget of tropical coastal ecosystems. Water, Air, Soil Pollution 64: 265-288.

[20] UNEP/CBD/SBSTTA/15/2. 2011. Suggested indicators for the Strategic Plan for Biodiversity 20112020 and the Aichi Biodiversity Targets. Note by the Executive Secretary. 5 August 2011.

[21] 2010 Biodiversity Indicators Partnership. 2010. Biodiversity indicators and the 2010 Target: Experiences and lessons learnt from the 2010 Biodiversity Indicators Partnership. Secretariat of the Convention on Biological Diversity; Montreal, Canada. Technical Series No. 53, 196 pages. 